\title{
The Mass Incarceration Bogeyman
}

\section{Barry Latzer}

One would be hard-pressed to find a criminal justice expert who doubts that the United States engages in mass incarceration. Just search the phrase in Google Scholar. You'll get about 171,000 results, virtually all assuming that our prisons and jails are filled with people who shouldn't be there. The implication is clear: we need to dramatically scale back these numbers.

The ACLU suggests that half of all prisoners should be released. ${ }^{1}$ The realities of imprisonment suggest otherwise. The federal Bureau of Justice Statistics regularly publishes data on the prison population, including the crimes of the inmates. The latest publication, Prisoners in 2018, states that there were 1,465,200 prisoners at the end of 2018. ${ }^{2}$ That's a big number, but maybe not for a nation of over 327 million, where it comes to less than .5 percent of the population.

When we look at the crimes of the inmates the case for disincarceration weakens considerably. Here are the facts. (These figures are for state, not federal, prison inmates, which comprise 89 percent of all prisoners.) $)^{3}$ As this table indicates, there aren't many prisoners being held for minor transgressions. A clear majority of inmates, 55.7 percent, were convicted of violent crimes. The rest of the crimes, such as burglary or weapons offenses, are serious, even if not inherently violent. And drug crimes, inaccurately blamed

1 American Civil Liberties Union, https://www.aclu.org/blog/smart-justice/mass-incarceration/wecan-cut-mass-incarceration-50-percent.

2 U.S. Dept. of Justice, Bureau of Justice Statistics, Prisoners in 2018 (2020), https://www.bjs.gov/ content/pub/pdf/p18.pdf. This essay discusses prison, not jail, inmates. On any given day there are approximately 745,200 people in jail, but this is a transient population, often confined for no more than a few days.

3 Ibid., table 13.

Barry Latzer is professor emeritus at John Jay College of Criminal Justice, CUNY; blatzer@jjay.cuny. edu. His history of violent crime pre-1940, The Roots of Violent Crime in America: From the Gilded Age through the Great Depression, will be published in 2021 by Louisiana State University Press. He is currently working on a critique of mass incarceration, tentatively titled The Myth of Overpunishment. It will be released by Republic Book Publishers in late 2021. Latzer last appeared in these pages with "The Futility of Gun Control as Crime Control," (Summer, 2019). 
for causing mass incarceration, are responsible for only 14.4 percent of the inmate count. Furthermore, a mere one in four drug inmates were convicted of possessing, as opposed to the much more serious crime of trafficking narcotics.

\begin{tabular}{|c|c|c|}
\hline Type of Crime & Percent of Prisoners & Offenses Included \\
\hline Violent & $55.7 \%$ & $\begin{array}{l}\text { Inludes murder, assault, rape, sexual } \\
\text { assault, and other crimes of violence. }\end{array}$ \\
\hline Property & $16.8 \%$ & $\begin{array}{l}\text { Includes burglary, fraud, and other } \\
\text { property crimes. }\end{array}$ \\
\hline Drug & $14.4 \%$ & $\begin{array}{l}\text { Includes } 3.7 \% \text { for possession, } 10.8 \% \text { for } \\
\text { trafficking and other drug offenses. }\end{array}$ \\
\hline Public Order & $12.4 \%$ & $\begin{array}{l}\text { Includes weapons crimes, driving while } \\
\text { intoxicated and other public order } \\
\text { offenses. }\end{array}$ \\
\hline
\end{tabular}

Source: U.S. Dept. of Justice, Bureau of Justice Statistics, Prisoners in 2018 (2020), table 13, https://www.bjs.gov/content/pub/ pdf/p18.pdf.

Not only are the offenses of prison inmates a genuine threat to the public, there is another reason to believe that a major downsizing of our prisons is imprudent, namely: recidivism. The Bureau of Justice Statistics tracked for nine years prisoners released from state facilities in $2005 .{ }^{4}$ What they found was shocking. The 401,288 released prisoners were arrested 1,994,000 times during the nine-year period, an average of five arrests per released prisoner. At the end of the nine years 83 percent of the discharged inmates had been rearrested.

Not only does recidivism indicate that release of prisoners is risky, it also helps explain why many defendants get long sentences. Aside from the seriousness of the crime, nothing affects sentencing more than the criminal history of the defendant.

Long sentences in turn raise our incarceration rates, a key rhetorical weapon in the arsenal of the anti-incarceration lobby. Imprisonment rates tell how many prisoners there are at the end of a year throughout the United States for every 100,000 of the entire population. Since rates are calculated annually prisoners who serve long sentences (due to the seriousness of their crimes plus their long criminal history) boost the nation's incarceration rates until they are released. The more long-term prisoners there are, the higher are incarceration rates (other considerations aside).

4 U.S. Dept. of Justice, Bureau of Justice Statistics, and 2018 Update On Prisoner Recidivism: A 9-Year Follow-Up Period (2005-2014), (2018), https://www.bjs.gov/content/pub/pdf/18upr9yfup0514.pdf. 
The latest imprisonment rate calculation (based on 2018 data and including federal prisoners but not jail inmates) is 431 per 100,000 U.S. residents. Is that high? It most certainly is if the benchmark is other democratic nations. European incarceration rates are much lower than ours. U.S. rates are approximately two-and-one-half times as great as those in the UK, for instance. ${ }^{5}$

So does that mean we really do engage in mass incarceration? If the phrase implies that we must sharply reduce our prison population then my answer is “no.” Here’s why.

There are three reasons for our high incarceration rates compared to other countries: recidivism, guns, and murder. As long as these factors sharply differentiate us from other nations our incarceration rates will remain much higher.

I already discussed the role of recidivism in boosting sentences, which in turn elevates incarceration rates. I would add the following. The United States suffered an enormous crime wave-a crime tsunami-beginning in the late 1960s and starting to decline in the early 1990s. Increased crime in Europe, Canada, Australia and other comparable countries came nowhere near the magnitude of our rates. From 1960 to 1990, violent crime in this country increased 353 percent-perhaps the biggest sustained increase in the nation's history. This led to huge numbers of arrests, convictions, and incarcerations, especially once the criminal justice system was toughened up. Arrests rose fourfold and prison commitments increased 350 percent. ${ }^{6}$ These subsequent convictions led to longer sentences, as one would expect for repeaters. And longer sentences, for the reasons offered above, mean higher incarceration rates.

The second reason for our high rates is the enormous number of firearms in this country and their use in the commission of crimes. Guns lead to stiffer sentences, either as elements of the crime (armed robbery, for example, sentenced more harshly than strong-arm robbery), or as sentencing enhancements (anywhere from one to five years added to a sentence when a gun is used in the commission of a crime).

Other countries have far fewer guns and far fewer gun crimes. From 2000 to 2012 there were an estimated 1,500 gun homicides per year in all of Europe, around 20 percent of total homicides. For a comparable period there were

5 Georgina Sturge, UK Prison Population Statistics (2020), 5, http://researchbriefings.files.parliament. uk/documents/SN04334/SN04334.pdf. The 2018 UK rate was 173 per 100,000.

6 Barry Latzer, The Rise and Fall of Violent Crime in America (New York: Encounter Books, 2016), chaps. 3,4 . 
nearly 12,000 annual gun homicides in the United States, eight times as many as Europe, and guns were responsible for 67 percent of all killings. In 1990, a peak year for murder here, the Western European firearm homicide rate was a mere 0.53 per 100,000. The United States rate was 5.57 per 100,000-ten and one-half times higher. ${ }^{7}$

Reason three, murder, is directly related to the firearms issue. As the statistics in the preceding paragraph indicate, we have many more murders than comparable countries due to our superabundance of guns. One major reason for this is that it is easier to slay people with a firearm as one doesn't even have to get close to the victim, to say nothing of the kill benefit from rapidfiring weapons. Unsurprisingly, murderers get longer sentences than other criminals, and this, too, ramps up incarceration rates.

There are, in short, good reasons for our relatively high incarceration rates, and despite a significant rate decline since 2008, we can expect that our standing among the world's democracies will remain unchanged. ${ }^{8}$

"Mass incarceration" has become a cliché, and as with most clichés, it conceals a lot of assumptions that may be misleading or simply erroneous. It's important to challenge these assumptions-especially when experts (and politicians) rely on them.

$7 \quad$ Nils Duquet and Maarten Van Alstein, Firearms and Violent Deaths in Europe: An Exploratory Analysis of the Linkages Between Gun Ownership, Firearms Legislation and Violent Death (Brussels, Belgium: Flemish Peace Institute, 2015), 25; Centers for Disease Control and Prevention, National Vital Statistics System, 2001-2012.

8 The imprisonment rate fell 15 percent, from 506 sentenced prisoners per 100,000 in 2008 to 431 in 2018. U.S. Dept. of Justice, Bureau of Justice Statistics, Prisoners in 2018. 